\title{
CULTURAL FIT AND ACADEMIC PERFORMANCE OF HIGHER EDUCATION STUDENTS
}

This study provided empirical evidence on the relationship between cultural fit and individual performance in an area where it is rarely investigated: the academic achievement of higher education students. The authors employed an adapted version of the Organizational Culture Assessment Instrument (OCAI) to estimate individuals' culture fit (as the inverse of the difference between the culture as it is perceived and as it is preferred by the respondents), and the indicator of students' performance was their semester grade average. Their sample consisted of 348 full time higher education students from a Hungarian university. Based on linear and rank correlation, as well as linear regression analyses the authors have found that higher education students' cultural fit tended to relate positively to their academic performance.

Keywords: organizational culture, person-culture fit, higher education, individual performance, OCAI

$\mathrm{O}$ ur article provides empirical evidence on the contribution of person-organization cultural fitness to the individual performance of higher education students. The study follows a management sciences point of view, thus we narrow down the notion of organizational culture (hereinafter OC) to models that are measurable with valid and reliable instruments.

OC became particularly important - and at the same time more interesting - for management researchers when the first convincing clues had been found about its impact on various organizational performance indicators, even on financial measures (for a summary see Schneider - Ehrhart - Macey, 2013). The search to understand the way organizational culture contributes to success was mainly focused on finding the type or attributes of culture that generally lead organizations to success (e.g. Kotter - Heskett, 1992). As the number of studies and the area of the investigation extended, significant differences were revealed among sectors and branches (see Lee - Yu, 2004), thus patterns of the relationship between $\mathrm{OC}$ and performance identified in one field cannot be applied directly to another.

The contribution of OC to organizational level performance, however, may not depend solely on the exact type or features of the culture itself. At this point, we entered another area of research. Both economics and management sciences know that the effect of the allocation of the workforce to jobs is far from negligible. From the human resource management point of view there are at least four dimensions of a successful match between the employment opportunity and the employee. These are the 'person-job fit', the 'person-group fit' (including the supervisor), the 'person-vocation fit', and the 'person-organization $(\mathrm{P}-\mathrm{O})$ fit' (Kristof-Brown - Zimmerman - Johnson, 2005). One aspect of the $\mathrm{P}-\mathrm{O}$ match is the 'cultural fit': i.e. how well the person fits to the OC (Meyer et al., 2010).

The current study examines the effect of cultural fit in higher education institutions (HEIs), focusing on non-employee members of the organizations (students) and a non-financial performance indicator (the academic perfor- mance of individual students). As far as the authors are aware, the significance of cultural factors in higher education students' performance has been analyzed multiple times, as will be presented in the literature review section, but not from our perspective. The previous studies we review tried to find the ideal culture or cultural features along several OC models, including the one we use. However, we could not find any attempt to measure the effect of cultural fitness itself. Other papers that focused their attention on the relationship between student performance and their institutional fit did not employ the OC models which feature in the management literature. Thus, the current study can contribute to the existing literature by narrowing the gap described above; partly via the new empirical results, but more importantly by finding proof that the cultural fit between student and institution can be related to individual academic performance, and that this fitness and this relationship are measurable. Measurability is crucial from the management point of view, since it is the basis of understanding and control. In other words, managers of HEIs may find our results useful as they offer a possible tool to influence their organization's performance.

In sum, our article seeks an answer to the following research question:

Does the cultural fit perceived by higher education students tend to relate positively to their individual academic performance?

Our data were collected at the University of Debrecen, Hungary. The selected OC model was the Competing Values Framework (CVF), and the measurement tool was an adapted version of the Organization Culture Assessment Instrument (OCAI); they will be introduced later in the article. The performance indicator was the students' self-reported average grade.

The paper is structured as follows. First, based on a literature review we establish the definitions used in our research. Second, on the basis of the previous studies we form a hypothesis for empirical testing. Third, we intro- 
duce our empirical examination: sample, methods and results. Finally, we answer the research question and the hypothesis, and reveal the limitations of our results and the possible directions for further research.

\section{Literature review}

Since our paper is primarily empirical, our review will focus on providing only the necessary background to the empirical analysis. In the first part of this section the concept of the OC as we use it in our analysis is defined, then a more specific area, the OC of higher education institutions (HEIs) is discussed by a review of empirical results from the literature.

\section{The concept of organizational culture}

The so called 'culture-excellence' approach emerged in the early 1980s as a new paradigm at that time, and as a response to increasing Japanese competitiveness (Burnes, 2009). The core concept of that paradigm was that culture determines performance.

Although at that time many writers criticized the methodological shortcomings of the approach (Carrol, 1983; Lawler, 1985), a long list of empirical studies demonstrated the impact of OC on organizational performance (see, for example, Cameron - Ettington, 1988; Gordon - DiTomaso, 1992; Trice - Beyer, 1993; Marcoulides Heck, 1993; Lim, 1995; Ogbonna - Harris, 2000; Hajnal, 2006; Fekete - Dimény, 2012; Klein - Wallis - Cooke, 2013; Schneider et al., 2013; Pinho - Rodrigues - Dibb, 2014).

As a result, today researchers and practitioners agree that $\mathrm{OC}$ exists and that it is a significant factor to take into consideration in organizational studies, although there is still little agreement on what the term 'organizational culture' covers (Alvesson, 2013; Schein, 2010; Van den Berg - Wilderom, 2004). Since research into culture lies at the intersection area of several social sciences (anthropology, sociology, social psychology, organizational behavior), a diversity of approaches and definitions have been developed (Schein, 1990); and many controversies highlighted which relate to the definition, to the measurement, or to the key dimensions of OC (Cameron - Quinn, 2006).

Cameron and Ettington (1988), after reviewing a representative sample of papers containing definitions of culture, found that among the most frequently mentioned notions were the following: cultures are enduring sets of values, beliefs and assumptions that characterize the organizations and individuals within the organizations.

We have found the following definition to be the most appropriate for our research: "the culture of a group can now be defined as a pattern of shared basic assumptions that was learned by a group as it solved its problems of external adaptation and internal integration, that has worked well enough to be considered valid and, therefore, to be taught to new members as the correct way to perceive, think, and feel in relation to those problems' (Schein, 2010, p. 18). This relatively new definition emphasizes that culture has an important role in the group's adaptation to the external environment and, as a consequence, it has an impact on performance.

Regarding the measurement issue, at least three different strategies can be used (Cameron - Quinn, 2006) and distinct research methodologies can be applied (Schein, 1990). (1) In the holistic approach the investigator engages in the observation, and tries to become part of the organization. (2) In the metaphorical and language approaches the investigators disclose cultural patterns with the help of language patterns in conversations, stories, and documents. (3) In the quantitative approach investigators use questionnaires or interviews to evaluate the attributes of the OC. In our analysis we will follow the third strategy.

When analyzing OC, researchers frequently apply models which have emerged out of certain dimensions to describe OCs. We can differentiate content and pattern dimensions (Cameron - Quinn, 2006). Content dimensions are aspects of an organization's culture which help to recognize it. Good examples of content dimensions are the following (Cameron - Quinn, 2006):

1. 'The dominant characteristics of the organization, or what the overall organization is like.

2. The leadership style and approach that permeate the organization.

3. The management of employees or the style that characterizes how employees are treated and what the working environment is like.

4. The organizational glue or bonding mechanisms that hold the organization together.

5. The strategic emphases that define what areas of emphasis drive the organization's strategy.

6. The criteria of success that determine how victory is defined and what gets rewarded and celebrated.'

The above six notions represent the content dimensions of the OC Assessment Instrument (hereafter OCAI) which we use in our empirical research. OCAI is a validated and accurate measurement tool in diagnosing important aspects of OC (Cameron - Quinn, 2006). With the help of this instrument it is possible to identify the current as well as the preferred OC. Among the several management areas where it can be a valuable diagnosing tool - e.g. team development (Suderman, 2012) and quality management (Basir et al., 2017) -, there is evidence that it is able to predict organizational performance (e.g. Gordon - DiTomaso, 1992; Iriana - Buttle - Ang, 2013).

Pattern dimensions refer to a cultural profile. In the management sciences literature a wide variety of pattern dimensions are mentioned, such as internal-external focus, speed, riskiness, participativeness, clarity, power distance, masculinity, and individualism (Cameron Ettington, 1988). Cultural strength, cultural congruence and cultural type are the most dominant, and most frequently analyzed, pattern dimensions in the literature. Cameron and Ettington (1988) found the effectiveness of organizations connected more strongly to the type of culture than to cultural congruence, or to the strength of a culture. Other studies found these three patterns (type, 
congruence, strength) to be equally important differentiating factors between high and low-performing companies (Kotter-Heskett, 1992).

The OCAI framework follows a sociological foundation as well as the functional approach (Cooke - Rousseau, 1988): it assumes that culture can be explained by certain dimensions, and that quantitative methodology is useful to analyze OCs (Cameron - Quinn, 2006). Since we will use this instrument in our empirical research in the rest of our literature review, we summarize several studies which have analyzed OC with quantitative methods, discuss cultural fit, and investigate the link between OC and organizational performance. Over the decades, many quantitative tools for diagnosing OC have been invented. We have already mentioned OCAI (Cameron - Quinn, 2006). Cooke and Rousseau (1988) used the OC Inventory to evaluate OC. Glaser and Zamanou (1987) diagnosed OC with OC Survey and incident interviews. They combined quantitative and qualitative methods in their research, similarly to Hofstede, Neuijen, Ohayv, and Sanders (1990). Hybrid methods are also present in OC analysis, like pattern matching introduced by Burchell and Kolb (2003).

\section{Organizational culture of HEls}

In the beginning, business organizations were at the center of research on OC, but most of the concepts, approaches and models can be used in the case of non-profit organizations as well. In our paper the institutional culture of a HEI will be analyzed, thus we present various research findings from this field. Studies of OC in higher education institutions (HEIs) vary both in the model they use and in the subjects they collect their data from (Kuh - Whitt,
1988; Tierney, 1988). Since there are far too many models available to a researcher, here we only mention some examples (see Table 1), rather than offering an exhaustive list.

Studies can focus on staff, on students, or on both. Among the 15 reviewed papers 11 focused only on the staff perspective (managers, lecturers, administrators, library workers). Three studies gathered data on the HEIs' OCs solely from the students; while both the staff and the students were the object of Zhu and Engels's (2014) research. As even our non-representative review of studies has been able to highlight, the OCAI framework is a popular measurement instrument in the OC analysis of educational institutions. Nine out of the fifteen papers presented in Table 1 employed this culture-diagnostic tool.

In the literature reviewed which used OCAI one can find clues about the culture types the students or the given staff perceive or prefer, and about the connections between culture types and innovativeness and student commitment; however, there is no evidence about the relationship between students' cultural fit and their academic performance. Knowing how important the area of person-organization $(\mathrm{P}-\mathrm{O})$ fit in general human resource management is (Chatman, 1989; Caldwell - O'Reilly, III 1990; O’Reilly III - Chatman - Caldwell, 1991; Lauver Kristof-Brown, 2001; Kristof-Brown et al., 2005; Adkins - Caldwell, 2004; Wei, 2013; Alfes - Shantz - Alahakone, 2016), the question of student-institution fit seem to be missing from the above list of research into the culture of HEIs. As we see it, this hiatus is present only when it is the management literature that analyses HEIs.

There are, however, other - non-managerial - areas of sci-

Table 1.

\section{Reviewed papers on Organizational Culture of HEls}

\begin{tabular}{|c|c|c|c|c|c|}
\hline Author(s) & Organization & Sample & Measurement tool & Research focus & Main result(s) \\
\hline $\begin{array}{l}\text { Pushnykh and } \\
\text { Chemeris (2006) }\end{array}$ & $\begin{array}{l}1 \text { university in } \\
\text { Russia }\end{array}$ & $\begin{array}{l}\text { staff members } \\
(\mathrm{N}<900)\end{array}$ & $\begin{array}{l}\text { modified OCAI } \\
\text { plus } 100 \text { interviews }\end{array}$ & $\begin{array}{l}\text { The appropriateness of the } \\
\text { OC }\end{array}$ & $\begin{array}{l}\text { Neither the current nor the pre- } \\
\text { ferred OC meet the challenges. }\end{array}$ \\
\hline $\begin{array}{l}\text { Fralinger and Olson } \\
(2007)\end{array}$ & $\begin{array}{l}1 \text { university in the } \\
\text { USA }\end{array}$ & $\begin{array}{l}\text { students } \\
(\mathrm{N}=50)\end{array}$ & OCAI & Current and preferred OC & $\begin{array}{l}\text { Perceived and preferred OCs are } \\
\text { clan culture. }\end{array}$ \\
\hline Shirbagi (2007) & $\begin{array}{l}1 \text { university from } \\
\text { India and } 1 \text { from } \\
\text { Iran }\end{array}$ & $\begin{array}{l}\text { lecturers } \\
(\mathrm{N}=333)\end{array}$ & $\begin{array}{l}\text { OCAI, OCQ } \\
\text { (Organizational } \\
\text { Commitment } \\
\text { Questionnaire) } \\
\end{array}$ & $\begin{array}{l}\text { The connection between } \\
\text { organizational commitment } \\
\text { and } \mathrm{OC}\end{array}$ & $\begin{array}{l}\text { There is a positive connection } \\
\text { between clan culture and organ- } \\
\text { izational commitment. }\end{array}$ \\
\hline $\begin{array}{l}\text { Ferreira and Hill } \\
(2008)\end{array}$ & $\begin{array}{l}2 \text { Portuguese uni- } \\
\text { versities }\end{array}$ & $\begin{array}{l}\text { staff members } \\
(\mathrm{N}=114)\end{array}$ & OCAI & $\begin{array}{l}\text { Comparison of OCs of a } \\
\text { private and a public owned } \\
\text { university }\end{array}$ & $\begin{array}{l}\text { There is no overall difference } \\
\text { between private and public } \\
\text { universities. }\end{array}$ \\
\hline $\begin{array}{l}\text { Kleijnen et al. } \\
(2009)\end{array}$ & $\begin{array}{l}18 \text { university de- } \\
\text { partments in the } \\
\text { Netherlands }\end{array}$ & $\begin{array}{l}\text { teaching staff } \\
(\mathrm{N}=266)\end{array}$ & OCAI & Current and preferred OC & $\begin{array}{l}\text { The experienced culture was } \\
\text { (moderately) flexibility- and } \\
\text { control oriented, the preferred } \\
\text { form being flexibility oriented. } \\
\text { Significant differences were } \\
\text { found among departments. }\end{array}$ \\
\hline $\begin{array}{l}\text { Balogh, Gaál and } \\
\text { Szabó (2011) }\end{array}$ & $\begin{array}{l}1 \text { Hungarian uni- } \\
\text { versity }\end{array}$ & $\begin{array}{l}\text { students } \\
(\mathrm{N}=1242)\end{array}$ & $\begin{array}{l}\text { OCAI, CQS } \\
\text { (Cultural } \\
\text { Intelligence Scale) }\end{array}$ & $\begin{array}{l}\text { Preferred OC and cultural } \\
\text { intelligence at a workplace. }\end{array}$ & $\begin{array}{l}\text { The majority of students would } \\
\text { prefer to be employed in a clan } \\
\text { culture, those with high cultural } \\
\text { intelligence prefer adhocracy. }\end{array}$ \\
\hline
\end{tabular}




\begin{tabular}{|c|c|c|c|c|c|}
\hline $\begin{array}{l}\text { Kleijnen at al. } \\
\text { (2011) }\end{array}$ & $\begin{array}{l}18 \text { departments at } \\
\text { universities in the } \\
\text { Netherlands }\end{array}$ & $\begin{array}{l}\text { teaching staff } \\
(\mathrm{N}=266)\end{array}$ & OCAI & $\begin{array}{l}\text { Teachers' conceptions of } \\
\text { quality and organisational } \\
\text { values. }\end{array}$ & $\begin{array}{l}\text { Teachers tend to show a neutral } \\
\text { preference for control-oriented } \\
\text { values and a high positive pref- } \\
\text { erence for flexibility. }\end{array}$ \\
\hline $\begin{array}{l}\text { Bencsik, Marosi, } \\
\text { and Döry (2012) }\end{array}$ & $\begin{array}{l}1 \text { university in } \\
\text { Hungary }\end{array}$ & $\begin{array}{l}\text { teaching staff } \\
(\mathrm{N} \text { is unknown) }\end{array}$ & $\begin{array}{l}\text { OEI } \\
\text { (Organizational } \\
\text { Effectiveness } \\
\text { Inventory), OCI } \\
\text { (Organizational } \\
\text { Culture Inventory) } \\
\end{array}$ & $\begin{array}{l}\text { Readiness of the HEI to } \\
\text { introduce a knowledge } \\
\text { management system }\end{array}$ & $\begin{array}{l}\text { The culture preferred by the } \\
\text { teaching staff more or less fits } \\
\text { with the culture needed by a } \\
\text { learning organization }\end{array}$ \\
\hline $\begin{array}{l}\text { Van der Velden } \\
\text { (2012) }\end{array}$ & $\begin{array}{l}2 \text { universities in } \\
\text { the UK }\end{array}$ & $\begin{array}{l}2 \times 4 \text { key staff }(\mathrm{N}= \\
8) \text { and document } \\
\text { analysis }\end{array}$ & $\begin{array}{l}\text { McNay's typology } \\
\text { extended by the } \\
\text { author }\end{array}$ & $\begin{array}{l}\text { How institutional culture } \\
\text { relates to engagement with } \\
\text { students. }\end{array}$ & $\begin{array}{l}\text { The preference of students is } \\
\text { a collegial, partnership-based } \\
\text { approach for "enhancement of } \\
\text { the student experience". }\end{array}$ \\
\hline $\begin{array}{l}\text { West-Moynes } \\
\text { (2012) }\end{array}$ & $\begin{array}{l}4 \text { publicly funded } \\
\text { colleges in Ontario, } \\
\text { USA }\end{array}$ & $\begin{array}{l}\text { administrative staff } \\
(\mathrm{N}=44)\end{array}$ & $\begin{array}{l}\text { OCAI, MSAI } \\
\text { (Management } \\
\text { Skills Assessment } \\
\text { Instrument) }\end{array}$ & $\begin{array}{l}\text { Current and preferred cul- } \\
\text { ture types and the manage- } \\
\text { ment skills of the adminis- } \\
\text { trators }\end{array}$ & $\begin{array}{l}\text { Consistency exists between } \\
\text { preferred dominant culture type } \\
\text { and management skills of ad- } \\
\text { ministrators. }\end{array}$ \\
\hline $\begin{array}{l}\text { Zhu and Engels } \\
\text { (2014) }\end{array}$ & $\begin{array}{l}6 \text { Chinese univer- } \\
\text { sities }\end{array}$ & $\begin{array}{l}\text { teachers } \\
(\mathrm{N}=186) \\
\text { and students } \\
(\mathrm{N}=865)\end{array}$ & $\begin{array}{l}\text { (OCES) } \\
\text { Organizational } \\
\text { Cultural } \\
\text { Environment } \\
\text { Survey } \\
\end{array}$ & $\begin{array}{l}\text { OC and instructional inno- } \\
\text { vation }\end{array}$ & $\begin{array}{l}\text { The features of OC affect the } \\
\text { perceived need for and the views } \\
\text { about innovation. }\end{array}$ \\
\hline $\begin{array}{l}\text { Chandler and } \\
\text { Heidrich (2014) } \\
\& \\
\text { Heidrich and } \\
\text { Chandler (2015) }\end{array}$ & $\begin{array}{l}1 \text { Hungarian col- } \\
\text { lege }\end{array}$ & $\begin{array}{l}\text { employees } \\
(\mathrm{N}=334)\end{array}$ & $\begin{array}{l}\text { OCAI, MOI } \\
\text { (Market } \\
\text { Orientation } \\
\text { Inventory), inter- } \\
\text { views }\end{array}$ & $\begin{array}{l}\text { Diversity of culture among } \\
\text { staff and this diversity's im- } \\
\text { pact on market orientation }\end{array}$ & $\begin{array}{l}5 \text { subcultures were identified } \\
\text { with varying market orientation. }\end{array}$ \\
\hline Zhu (2015) & $\begin{array}{l}6 \text { Chinese univer- } \\
\text { sities }\end{array}$ & $\begin{array}{l}\text { lecturers } \\
(\mathrm{N}=684)\end{array}$ & OCS (OC Scales) & $\begin{array}{l}\text { OC of Chinese HEIs, and its } \\
\text { relationship to and } \\
\text { teachers' perceptions, } \\
\text { responsiveness and imple- } \\
\text { mentation of technology-en- } \\
\text { hanced } \\
\text { innovation }\end{array}$ & $\begin{array}{l}\text { OC is associated with teachers' } \\
\text { perception of and responsive- } \\
\text { ness to innovation and imple- } \\
\text { mentation of technology-en- } \\
\text { hanced innovation. }\end{array}$ \\
\hline $\begin{array}{l}\text { Castellanos et al. } \\
\text { (2016) }\end{array}$ & $2 \mathrm{HEI}$ in the USA & $\begin{array}{l}\text { students } \\
(\mathrm{N}=238)\end{array}$ & $\begin{array}{l}\text { UES (University } \\
\text { Environment } \\
\text { Scale), CCS } \\
\text { (Cultural } \\
\text { Congruity Scale) }\end{array}$ & $\begin{array}{l}\text { Cultural-fit vs. college and } \\
\text { life satisfaction }\end{array}$ & $\begin{array}{l}\text { Perception of the university } \\
\text { environment was the strongest } \\
\text { positive predictor of college } \\
\text { satisfaction, whereas cultural } \\
\text { congruity was the strongest } \\
\text { predictor of life satisfaction. }\end{array}$ \\
\hline Du Mérac (2015) & $\begin{array}{l}\text { Public secondary } \\
\text { schools in Rome. }\end{array}$ & $\begin{array}{l}\text { students }(\mathrm{N}=600) \\
\text { and Scouts }(\mathrm{N}= \\
231) \text { in upper sec- } \\
\text { ondary school }\end{array}$ & $\begin{array}{l}\text { ECPQ (Educational } \\
\text { Context Perception } \\
\text { Questionnaire) }\end{array}$ & $\begin{array}{l}\text { Compare the impact of the } \\
\text { school environment to } \\
\text { the Scouting environment } \\
\text { on the leadership attitudes. }\end{array}$ & $\begin{array}{l}\text { The impacts are different be- } \\
\text { tween } \\
\text { students and Scouts. }\end{array}$ \\
\hline $\begin{array}{l}\text { Chidambranathan } \\
\text { and Regha (2016) }\end{array}$ & $\begin{array}{l}40 \text { higher educa- } \\
\text { tion libraries in } \\
\text { the United Arab } \\
\text { Emirates }\end{array}$ & $\begin{array}{l}\text { employees } \\
(\mathrm{N}=263)\end{array}$ & OCAI & $\begin{array}{l}\text { The current and the pre- } \\
\text { ferred OC }\end{array}$ & $\begin{array}{l}\text { Clan and adhocracy character- } \\
\text { ize the perceived OC. Stronger } \\
\text { clan and adhocracy, while weak } \\
\text { market and hierarchy features } \\
\text { are preferred. }\end{array}$ \\
\hline Basir et al. (2017) & $\begin{array}{l}2 \text { Malaysian uni- } \\
\text { versities }\end{array}$ & $\begin{array}{l}\text { key personnel } \\
(\mathrm{N}=22)\end{array}$ & $\begin{array}{l}\text { semi-structured in- } \\
\text { terviews developed } \\
\text { by the authors }\end{array}$ & $\begin{array}{l}\text { The connection between } \\
\text { cultural dimensions (aca- } \\
\text { demic freedom, individu- } \\
\text { alism, professionalism, and } \\
\text { collegiality) and quality } \\
\text { management }\end{array}$ & $\begin{array}{l}\text { Academic freedom, individual- } \\
\text { ism and collegiality had worked } \\
\text { against ISO maintenance. The } \\
\text { opposites of individualism and } \\
\text { collegiality had supported ISO } \\
9001 \text {. }\end{array}$ \\
\hline
\end{tabular}

ence (sociology, educational sciences), where researchers have already revealed the importance of student-institution fit, and within this, the match between students and the cultural aspects of the institution concerning the academic performance of higher education students. Nonetheless, in this line of research the use of the culture diagnosis tools invented in the management literature are rarely employed.

As Bowman and Denson (2014) stated, student-institution fit is an important but empirically under-researched area of higher education studies. They could only find a few studies focusing on this question, and we also only came across one study published after 2014, by Sommet et al. (2015). Bowman and Denson (2014) revealed six factors, and found that a better fit leads to greater college satisfaction, lower social isolation, and indirectly to a stronger intention to persist with studies. Although the various factors (religious, athletic, academic, socio-economic, political, social) do not echo any OC model, they are all strongly connected to cultural aspects.

Sommet et al. (2015) are more explicit in stating that 
in addition to economic and social factors, psychological reasons might also be responsible for lower student-institution fit and, through this, also for weaker achievement. They also pointed out that papers measuring the contribution of Bourdieu's 'social capital' to students' achievement may also support the idea that cultural factors play an important role in one's academic performance, referring to the works by Stephens et al. (2012), Stephens, Townsend, Markus, and Phillips (2012), and Stephens, Hamedani, and Destin (2014).

The papers mentioned above measured cultural mismatch as the lack of a fit between the 'cultural models of self', brought from the family and the pre-higher education background, and the models of self that are prevalent in the college culture, focusing on the dichotomy of interdependent-independent norms. In their examination students' achievement variables are cortisol level, various psychosocial outcomes, and end-of-year grade point averages. The evidence they found shows a significant positive relationship between cultural fitness and the academic outcomes measured.

In sum, the findings of Bowman and Denson (2014), as well as those of Sommet et al. (2015) can support the idea that our research question is grounded and that we can hypothesize the existence of a positive relationship between the student-institution fit and the students' academic achievement. The study by Stephens et al. (2014) is, however, closest to the present research.

The core difference is that the current study uses a managerial perspective on $\mathrm{OC}$, and with this comes the use of the OCAI model, as a widely used, easy to administer diagnostic tool. Thus, the hypothesis for the empirical examination is formulated as follows:

The further a student feels the culture of their faculty (perceived culture) falls from its ideal state (preferred culture) the weaker the same student's academic performance is.

\section{Method and Data}

To reveal the OC the students perceived and preferred at their faculty we employed a version of the OC Assessment Instrument (OCAI) questionnaire published by Cameron and Quinn (2006), translated into Hungarian and adapted for the target group. The six dimensions of the OCAI instrument have been briefly introduced in the literature review section of this paper. The main modification we made was the omission of the sixth dimension ('Criteria of Success'), because after discussing the questionnaire with the master level students - who also conducted the data collection - we found it irrelevant: the respondents simply lack the necessary information on this item. Other changes affected only the wording: again, with the help of our students we adapted it to the situation, viewpoint, and knowledge level of a bachelor student.

As the literature review in the previous section showed, the management literature about the relationship between $\mathrm{OC}$ and performance in HEIs investigated the average perceived and/or preferred culture on the institutional level. Contrarily, in the present study the unit of analysis is the individual student. Thus, it examines the connection between individual students' cultural fit (according to their own perception) and their grade average. For this analysis neither the average institutional culture nor the average preferred culture is important, only the difference between the individual's perception of, and preference for, the organizational culture.

Distance between the preferred and the perceived cultures will be measured both (1) as the absolute value of the difference between the student-assigned preferred and the perceived values along each of the four cultures of the Competing Values Framework (thus there will be four differences for clan, adhocracy, market and hierarchy cultures) and (2) as the minimum, mean and maximum of these four absolute avalues.

According to our hypothesis, we expect that the greater the absolute value of the cultural mismatch (the difference between the faculty culture types its students prefer and the ones they perceive) the lower the students' academic performance.

We gathered some additional data via the questionnaire about the respondents' background, as well. In the further part of our study we will use the following elements of this information: the respondent's major(s), the semester they started their university studies in, their sex, year of birth, place of residence (name of the settlement), highest level of schooling, whether or not they have a job while engaged in their university studies, and the percentage of the university seminars and lectures they attend in the semester of the survey (measured by five categories: $0 \%, 1-20 \%, 21-40 \%, 41-60 \%, 61-80 \%, 81-100 \%)$. This background information is used only to provide a context to the investigation of the relationship between individual cultural fit and individual student performance in higher education. Thus, we do not intend to draw conclusions on the role of the background variables, but we will use them as control variables in multivariable regression analysis.

The questionnaire survey was conducted at the University of Debrecen, Hungary. This higher educational institution has a long tradition going back over more than 450 years (UD, 2018). Its predecessor, the Reformed College of Debrecen, was established in 1538. Later in 1912 the Hungarian Parliament established the Hungarian Royal University of Debrecen with five faculties. After the Second World War the university was disintegrated into three institutions. The Faculty of Theology was separated and returned to the Calvinist Church (as Debrecen Reformed Theological Academy that was the predecessor of the current Debrecen Reformed Theological University), the Faculty of Law was suspended, and the Medical University of Debrecen and the Lajos Kossuth University began their independent operation. From the beginning of 1980 s the idea of reunification was already under discussion, but the merger took place only on January 1, 2000. Currently the University of Debrecen, where our research took place, has more than 25000 students at 14 faculties. In addition to its Hungarian programmes the university offers 51 programmes in foreign languages. 
Our data were collected from students studying on eight majors at four faculties at the University of Debrecen, Hungary. Students of the Faculty of Economics and Business (FEB), the Faculty of Engineering (FE), and the Faculty of Informatics (FI) were surveyed during November 2015 (the data collection was conducted by master students), while students from the Faculty of Science and Technology (FST) filled in the questionnaires (collected by instructors) during December in the same year. Everyone in the sample studied at the bachelor level, on one of the following majors. FEB students: Business Economics and Management (BEM); FI students: Engineering Information Technology (EIT) or Software Information Technology (SIT); FE students: Technical Management (TM); FST students: Biology (BIO), Geography (GEG), Geology (GEL), or Chemistry (CHE).

The nominal performance of the students was very likely biased by the different courses they had to complete. Since course-sets depend on the major and also on the year, we have standardized the reported performance by the respondent's major and the semester in which he/ she started his/her university studies, in order to minimize this bias. To further refine our dataset we have omitted from the sample those who belonged to a combination of major and starting semester where the number of students was lower than 9, who had already graduated at bachelor level, who had more than one major, and also those who visited less than $21 \%$ of the classes ( 5 people). Given these constraints, the structure of the final sample by faculty, major, sex and starting semester is presented in Table 2 and the unstandardized student performance is shown in Table 3 by major and semester of enrolment. Variance analyses (one-way ANOVA) were conducted to reveal the significance of the potential grade bias by the major (see the last column of Table 3) and by the semester of enrolment (bottom row of Table 3); and only the major-bias was demonstrated to be significant in the fall semester of the starting year 2014.

Table 2.

Structure of the sample by faculty, major, sex and starting semester

\begin{tabular}{|c|c|c|c|c|c|c|c|c|}
\hline \multirow{3}{*}{ Faculty } & \multirow{3}{*}{ Major } & \multicolumn{6}{|c|}{ Starting semester } & \multirow{3}{*}{ Total } \\
\hline & & \multicolumn{2}{|c|}{ Fall 2012} & \multicolumn{2}{|c|}{ Fall 2013} & \multicolumn{2}{|c|}{ Fall 2014} & \\
\hline & & Male & Female & Male & Female & Male & Female & \\
\hline FEB & BEM & 0 & 0 & 14 & 25 & 19 & 39 & 97 \\
\hline \multirow[b]{2}{*}{ FI } & EIT & 14 & 2 & 15 & 1 & 12 & 0 & 44 \\
\hline & SIT & 0 & 0 & 10 & 2 & 13 & 0 & 25 \\
\hline \multirow[t]{2}{*}{ FE } & TM & 0 & 0 & 27 & 19 & 27 & 18 & 91 \\
\hline & $\mathrm{BIO}$ & 0 & 0 & 0 & 0 & 16 & 36 & 52 \\
\hline \multirow{3}{*}{ FST } & GEG & 0 & 0 & 0 & 0 & 7 & 11 & 18 \\
\hline & GEL & 0 & 0 & 0 & 0 & 5 & 4 & 9 \\
\hline & $\mathrm{CHE}$ & 0 & 0 & 0 & 0 & 6 & 6 & 12 \\
\hline & & 14 & 2 & 66 & 47 & 105 & 114 & 348 \\
\hline
\end{tabular}

Table 3.

Unstandardized grade-means by major and starting semester

\begin{tabular}{|c|c|c|c|c|c|c|c|c|c|c|c|}
\hline \multirow{2}{*}{\multicolumn{2}{|c|}{$\begin{array}{c}\text { Semester } \\
\text { BEM }\end{array}$}} & \multicolumn{9}{|c|}{ Major } & \multirow{2}{*}{$\mathrm{F}$} \\
\hline & & EIT & SIT & TM & BIO & GEG & GEL & CHE & Total & & \\
\hline \multirow{3}{*}{$\begin{array}{l}2012 \\
\text { Fall }\end{array}$} & M & - & 3.375 & - & - & - & - & - & - & 3.375 & \\
\hline & S.D. & - & 0.719 & - & - & - & - & - & - & 0.719 & \\
\hline & $\mathrm{N}$ & - & 16 & - & - & - & - & - & - & 16 & \\
\hline \multirow{3}{*}{$\begin{array}{l}2013 \\
\text { Fall }\end{array}$} & M & 3.308 & 3.313 & 3.083 & 3.261 & - & - & - & - & 3.265 & \multirow{3}{*}{0.488} \\
\hline & S.D. & 0.569 & 0.704 & 0.515 & 0.575 & - & - & - & - & 0.583 & \\
\hline & $\mathrm{N}$ & 39 & 16 & 12 & 46 & - & - & - & - & 113 & \\
\hline \multirow{3}{*}{$\begin{array}{l}2014 \\
\text { Fall }\end{array}$} & M & 3.491 & 3.500 & 2.846 & 3.322 & 3.558 & 3.556 & 3.333 & 3.333 & 3.425 & \multirow{3}{*}{$1.986^{*}$} \\
\hline & S.D. & 0.716 & 0.674 & 0.689 & 0.792 & 0.608 & 0.705 & 0.500 & 0.492 & 0.697 & \\
\hline & $\mathrm{N}$ & 58 & 12 & 13 & 45 & 52 & 18 & 9 & 12 & 219 & \\
\hline $\mathrm{F}$ & & 1.799 & 0.248 & 0.938 & 0.180 & & & & & 2.146 & \\
\hline
\end{tabular}

Note: $M=$ mean; $S . D .=$ standard deviation,

$F=$ ANOVA $F$ statistic, ${ }^{*} p<0.10$

To identify whether and how cultural fit and grade performance are connected statistically, we first identify linear correlations and rank correlations between the - signed and absolute - values of cultural mismatch (measured as the differences between preferred and perceived cultures) and the standardized self-reported average grade of the students. The findings will be reinforced with multivariate linear regression analysis where the relationships are tested in the presence of other available independent variables (sex, age, habitation, secondary school type, self-reported class attendance rate, being employed or not). During these investigations the variables defined in Table 4 will be used.

Table 4 .

\section{Definitions of the variables}

\begin{tabular}{l|l}
\hline Name & Definition \\
\hline SEX & 0 if the respondent is male, 1 if female \\
\hline AGE & $\begin{array}{l}\text { The respondent's age estimated as the difference between the } \\
\text { survey date and the middle (1st July) of the year of birth. }\end{array}$ \\
\hline LOCAL & $\begin{array}{l}0 \text { if the respondent's place of residence is not in the university's } \\
\text { city, } 1 \text { if it is. }\end{array}$ \\
\hline VOCED & $\begin{array}{l}0 \text { if the respondent's highest completed education level is aca- } \\
\text { demic secondary school, } 1 \text { if it is vocational secondary school. }\end{array}$ \\
\hline ATT41 & $\begin{array}{l}0 \text { if the student reported minimum attendance rate on seminars } \\
\text { and lectures in the current semester as a maximum of } 40 \% \text { on } \\
\text { average, } 1 \text { if the average attendance rate is a minimum of } 41 \% .\end{array}$ \\
\hline ATT61 & $\begin{array}{l}0 \text { if the minimum attendance rate is reported to be less than } 61 \% \\
\text { (in the current semester, on average), } 1 \text { if it is equal or higher. }\end{array}$ \\
\hline ATT81 & $\begin{array}{l}0 \text { if the minimum attendance rate is reported to be less than } 81 \% \\
\text { (in the current semester, on average), } 1 \text { if it is equal or higher. }\end{array}$ \\
\hline JOB & $\begin{array}{l}0 \text { if the respondent has no job while engaged on his/her universi- } \\
\text { ty studies, } 1 \text { if he/she has. }\end{array}$ \\
\hline PERF & $\begin{array}{l}\text { The self-reported average grade performance in the previous se- } \\
\text { mester(s) rounded to a single digit from } 1 \text { to } 5 .\end{array}$ \\
\hline ZPERF & PERF standardized by major and starting year. \\
\hline CLAN & $\begin{array}{l}\text { The degree to which the OC of the faculty is perceived by the } \\
\text { respondent to be a clan culture. Ranging from 0 to } 100 .\end{array}$ \\
\hline ADHO & $\begin{array}{l}\text { The degree to which the OC of the faculty is perceived by the } \\
\text { respondent to be an adhocracy culture. From } 0 \text { to } 100 .\end{array}$ \\
\hline MARK & $\begin{array}{l}\text { The degree to which the OC of the faculty is perceived by the } \\
\text { respondent to be a market culture. } 0 \text {-100. }\end{array}$ \\
\hline
\end{tabular}




\begin{tabular}{l|l}
\hline HIER & $\begin{array}{l}\text { The degree to which the OC of the faculty is perceived by the } \\
\text { respondent to be a hierarchy. 0-100. }\end{array}$ \\
\hline pCLAN & $\begin{array}{l}\text { The degree to which the respondent would prefer a clan culture } \\
\text { as the OC of its faculty. From 0 to 100. }\end{array}$ \\
\hline pADHO & $\begin{array}{l}\text { The degree to which the respondent would prefer an adhocracy } \\
\text { as the OC of its faculty. 0-100. }\end{array}$ \\
\hline pMARK & $\begin{array}{l}\text { The degree to which the respondent would prefer a market cul- } \\
\text { ture as the OC of its faculty. 0-100. }\end{array}$ \\
\hline pHIER & $\begin{array}{l}\text { The degree to which the respondent would prefer a hierarchy as } \\
\text { the OC of its faculty. 0-100. }\end{array}$ \\
\hline DIFclan & $\begin{array}{l}\text { The degree to which the respondent would like its faculty's cul- } \\
\text { ture to be a clan compared to its current state. Equals pCLAN } \\
\text { minus CLAN. }\end{array}$ \\
\hline DIFadho & Equals pADHO minus ADHO. \\
\hline DIFmark & Equals pMARK minus MARK. \\
\hline DIFhier & Equals pHIER minus HIER. \\
\hline ADIFclan & $\begin{array}{l}\text { The degree to which the preferred and the perceived clan cultures } \\
\text { on the faculty differ from each other, according to the respond- } \\
\text { ent, independently of the direction of the difference. Equals the } \\
\text { absolute value of DIFclan. }\end{array}$ \\
\hline ADIFadho & Equals the absolute value of DIFadho. \\
\hline ADIFmark & Equals the absolute value of DIFmark. \\
\hline ADIFhier & Equals the absolute value of DIFhier. \\
\hline minADIF & $\begin{array}{l}\text { The smallest difference, in absolute value, between the preferred } \\
\text { and perceived culture in any of the four culture types. Equals the } \\
\text { minimum of ADIFclan, ADIFadho, ADIFmark and ADIFhier. }\end{array}$ \\
\hline aveADIF & $\begin{array}{l}\text { Equals the mean of ADIFclan, ADIFadho, ADIFmark and } \\
\text { ADIFhier. }\end{array}$ \\
\hline & $\begin{array}{l}\text { Equals the maximum of ADIFclan, ADIFadho, ADIFmark and } \\
\text { ADIFhier. }\end{array}$ \\
\hline
\end{tabular}

In the total sample the average estimated age (AGE) was 21.166 years (standard deviation is 1.546 years, the number of missing responses is 2), the number of those living in the university city (LOCAL) was 101 (with 9 missing answers), the highest educational level was secondary vocational school (VOCED) in 118 cases and secondary academic school in the remaining 230 cases. 142 people were employed at the time of the survey (JOB). Of the 348 respondents everyone reported a minimum $21 \%$ attendance rate. 312 of them were present at least $41 \%$ (ATT41), 235 at least 61\% (ATT61), and 102 at more than 80\% (ATT81) of the classes in the semester when the survey was conducted.

\section{Results}

To create a context for the examination of the core research questions, we first describe the OCs of the eight majors according to the four culture types of the Competing Values Framework (CVF). In Table 5 data on the means and standard deviations of the average scores assigned to the perceived and preferred cultures by the respondents are presented, along with one-sample $t$-statistics measuring the significance of the difference of the mean cultural values from the value of a neutral culture (i.e. 25 , if the 100 points are randomly distributed among the four culture types). In 33 of the 64 cases (two times four culture types in eight majors), i.e. in approximately half of the tests we had run, the mean of the assigned scores were different from the 'neutral' value at the $5 \%$ level of significance.
To investigate the cultural diversity among the eight majors, ANOVA tests were also conducted along every perceived and preferred culture type. Majors were found to be different from each other in every case on at least the $5 \%$ significance level, without exception. Not wanting to duplicate the information already present in Table 5 we mention only one example to show how to understand these data. Regarding BEM students, the data indicates that they sensed a weak clan (significantly lower than 25 ), weak adhocracy (significantly lower than 25), strong market (significantly higher than 25) and strong hierarchy culture (significantly higher than 25 ), while the same respondents revealed that their ideal culture was a strong clan (significantly higher than 25) and strong hierarchy (significantly higher than 25), an average adhocracy (does not differ significantly from 25), and a weak market culture (significantly lower than 25).

Table 5.

\section{Perceived and preferred cultures by major}

\begin{tabular}{|c|c|c|c|c|c|c|c|c|c|c|}
\hline \multirow{4}{*}{\multicolumn{2}{|c|}{$\begin{array}{c}\text { Type } \\
\text { BEM } \\
N=97\end{array}$}} & FEB & \multicolumn{2}{|c|}{ FI } & FE & \multicolumn{4}{|c|}{ FST } & \multirow{4}{*}{$F$} \\
\hline & & \multirow{3}{*}{$\begin{array}{c}\text { EIT } \\
N= \\
44\end{array}$} & SIT & TM & BIO & GEG & GEL & CHE & & \\
\hline & & & $N=$ & $N=$ & $N=$ & $N=$ & & $N=$ & & \\
\hline & & & 25 & 91 & 52 & 18 & $=9$ & 12 & & \\
\hline & Mean & & 19.275 & 23.200 & 27.440 & 25.219 & 31.722 & 23.333 & 25.333 & \\
\hline CLAN & S.D. & 7.291 & 6.783 & 6.819 & 7.213 & 7.123 & 11.488 & 9.579 & 8.117 & $8.601^{* * *}$ \\
\hline & $t$ & $-3.347^{7+1}$ & $-5.598^{+1+4}$ & -1.320 & $3.2266^{* 3+}$ & 0.222 & $2.483^{3 *}$ & -0.522 & 0.142 & \\
\hline & Mean & 23.464 & 21.289 & 22.440 & 25.602 & 24.700 & 23.500 & 21.222 & 23.500 & \\
\hline ADHO & S.D. & 6.078 & 8.485 & 6.378 & 4.690 & 5.730 & 5.732 & 7.480 & 7.205 & $2.778^{* * *}$ \\
\hline & $t$ & $-2.489^{* *}$ & $-2.901^{*+4}$ & $-2.007^{7}$ & 1.225 & -0.378 & -1.110 & -1.515 & -0.721 & \\
\hline & Mean & 26.680 & 30.193 & 29.960 & 22.969 & 23.977 & 19.611 & 25.556 & 26.833 & \\
\hline MARK & S.D. & 8.033 & 10.062 & 11.081 & 6.724 & 7.229 & 7.204 & 12.875 & 11.216 & $6.010^{* * *}$ \\
\hline & $t$ & $2.060^{* *}$ & $3.423^{* * *}$ & $2.238^{* *}$ & $-2.881^{* * *}$ & -1.021 & $-3.174^{* * *}$ & 0.129 & 0.566 & \\
\hline & Mean & 27.334 & 29.243 & 24.400 & 23.989 & 26.104 & 25.167 & 29.889 & 24.333 & \\
\hline HIER & S.D. & 8.104 & 9.501 & 8.010 & 4.387 & 5.880 & 8.900 & 6.791 & 5.331 & $3.495^{* * *}$ \\
\hline & $t$ & $2.836^{* *}$ & $2.962^{* * *}$ & -375 & $-2.198^{* \prime}$ & 1.354 & 0.079 & $2.160^{*}$ & -0.433 & \\
\hline & Mean & 27.920 & 27.845 & 26.968 & 27.435 & 31.192 & 35.056 & 28.778 & 30.583 & \\
\hline pCLAN & S.D. & 7.199 & 7.853 & 4.228 & 5.977 & 7.027 & 9.613 & 7.085 & 4.907 & $4.256^{* * *}$ \\
\hline & $t$ & $3.995^{5+2}$ & $2.403^{* *}$ & $2.327^{7 *}$ & $3.886^{\prime \prime \prime}$ & $6.355^{\mathrm{t+1}}$ & $4.438^{\text {t+t }}$ & 1.600 & $\left.3.94\right|^{\text {tw }}$ & \\
\hline & Mean & 24.374 & 26.505 & 26.760 & 25.963 & 26.650 & 24.556 & 23.667 & 26.167 & \\
\hline $\mathrm{pADHO}$ & S.D. & 4.440 & 4.607 & 4.608 & 4.004 & 3.792 & 5.147 & 3.202 & 5.271 & $2.623^{* *}$ \\
\hline & $t$ & -1.389 & $2.167^{7 x}$ & $1.910^{*}$ & $2.293^{3 *}$ & $3.138^{* * 8}$ & -0.366 & -1.249 & 0.767 & \\
\hline & Mean & 21.379 & 22.909 & 22.472 & 22.066 & 17.892 & 17.333 & 22.444 & 19.000 & \\
\hline pMARK & \begin{tabular}{|l} 
S.D. \\
\end{tabular} & 6.142 & 6.700 & 5.178 & 5.944 & 5.343 & 5.111 & 12.660 & 6.045 & $4.281^{* * *}$ \\
\hline & $t$ & $5.807^{\text {tw" }}$ & $-2.070^{* *}$ & $-2.441^{*}$ & $-4.709^{* t s}$ & $-9.593^{* \text { *w }}$ & $-6.365^{3 * t}$ & -0.606 & $-3.438^{+4+1}$ & \\
\hline & Mean & 26.328 & 22.741 & 23.800 & 24.536 & 24.265 & 23.056 & 25.111 & 24.250 & \\
\hline pHIER & S.D. & 5.219 & 4.713 & 4.186 & 4.388 & 4.988 & 6.412 & 5.667 & 4.181 & $3.042^{* * *}$ \\
\hline & $t$ & $2.506^{* 8}$ & $-3.180^{* * n+4}$ & -1.433 & -1.008 & -1.062 & -1.287 & 0.059 & -0.621 & \\
\hline
\end{tabular}

Note: S.D. = standard deviation, $t=$ one-sample $t$-test (test value is zero), $F=$ ANOVA F statistic, ${ }^{*} p<0.10,{ }^{* *} p<0.05,{ }^{* * *} p<0.01$.

After identifying the various cultures perceived or preferred by the students on different majors we also tested whether there is a gap between the preferred and perceived cultures (measured via variables whose names begin with 'ADIF', described in Table 4) on the level of individual students, and if the size of these gaps is statistically connected to the students' (self-reported) performance or not. Since the performance of students from different majors could not be compared without a significant bias (because tests, teachers, required skill and many other things are 
different) we will conduct the analysis only on the individual level, employing the standardized version (by major and by year) of the self-reported performance (ZPERF, see Table 4). Table 6 reports the results of one-sample $t$-tests, comparing the mean of ZPERF to the test value zero. Because it is trivial to assume that those visiting more classes sense OC differently from those not present as frequently during the course (and they would probably be familiar with a different type of culture, too) we conduct the testing on the basis of minimum attendance rate. Here we would like to note that attendance rate can naturally affect the preferred and perceived cultures presented in Table 5 as well, but since it is not directly necessary to answer our main questions, and since the sample size would be too small in the majority of the attendance rate vs. major combinations, we skip the analysis of the impact of attendance on culture at the major level. Although the questionnaire asked the students in relation to their faculty, this would still not be a good level of aggregation, because the respondents were recruited only from 1 to 4 majors of each faculty, so it would be far from representative.

The results in Table 6 show that preferred and perceived cultures differ significantly in the whole sample on the individual level (we did not take the major or the faculty into consideration) at every attendance rate. In the last column of the table $F$-test results are shown, which test the connection between minimum attendance level and (signed and absolute) cultural mismatch: this is not significant at the $5 \%$ level for any of the culture types.

Table 6.

Significance test of cultural mismatch by attendance rate

\begin{tabular}{c|c|c|c|c|c}
\hline \multirow{2}{*}{ Culture type } & \multicolumn{4}{|c|}{ One-sample $t$-tests (test value $=0$ ) } & \multirow{2}{*}{$F$} \\
\cline { 2 - 5 } & $21 \%$ subsamples by minimum attendance & \\
\hline DIFclan & $10.188^{* * *}$ & $9.558^{* * * *}$ & $7.418^{* * *}$ & $5.234^{* * *}$ & 1.319 \\
\hline DIFadho & $5.078^{* * *}$ & $4.754^{* * *}$ & $4.435^{* * *}$ & $1.902^{*}$ & 0.715 \\
\hline DIFmark & $-9.171^{* * *}$ & $-8.784^{* * *}$ & $-7.431^{* * *}$ & $-4.982^{* * *}$ & 0.044 \\
\hline DIFhier & $-3.672^{* * *}$ & $-3.224^{* * *}$ & $-1.950^{*}$ & -0.286 & 1.821 \\
\hline ADIFclan & $19.336^{* * *}$ & $19.311^{* * *}$ & $16.211^{* * *}$ & $9.962^{* * *}$ & $2.253^{*}$ \\
\hline ADIFadho & $18.670^{* * *}$ & $17.683^{* * *}$ & $15.618^{* * *}$ & $10.050^{* * *}$ & 0.736 \\
\hline ADIFmark & $16.981^{* * *}$ & $16.247^{* * *}$ & $14.216^{* * *}$ & $8.781^{* * *}$ & 0.831 \\
\hline ADIFhier & $17.955^{* * *}$ & $17.536^{* * *}$ & $15.109^{* * *}$ & $9.595^{* * *}$ & 0.817 \\
\hline$N$ & 348 & 312 & 235 & 102 & \\
\hline
\end{tabular}

We also know from the same table, that the means of the signed differences are different from zero, too - with the only exception being hierarchy culture in the subsample of students with class attendance above $60 \%-$, which means that the cultural mismatch has a direction: students tend to perceive the present clan and adhocracy cultures to be weaker, while the market and (only in the samples with a minimum 21 or $41 \%$ attendance) hierarchy cultures to be stronger than preferred.
Now that the presence of gaps in the students' cultural fit is supported, we can investigate their relationship to the standardized (self-reported) performance. First, let us see what linear and rank correlation analyses show (see Table 7), not taking the possible moderator variables into consideration.

Table 7.

Linear and rank correlations between the standardized performance (ZPERF) and the variables of cultural fit

\begin{tabular}{c|c|c|c|c|c|c|c|c}
\hline \multirow{2}{*}{$\begin{array}{c}\text { Cultural } \\
\text { variable }\end{array}$} & \multicolumn{3}{|c|}{$\begin{array}{c}\text { Pearson correlation by min. } \\
\text { attendance }\end{array}$} & \multicolumn{4}{c}{$\begin{array}{c}\text { Spearman's rho by min. at- } \\
\text { tendance }\end{array}$} \\
\cline { 2 - 9 } & $21 \%$ & $41 \%$ & $61 \%$ & $81 \%$ & $21 \%$ & $41 \%$ & $61 \%$ & $81 \%$ \\
\hline $\mathrm{N}$ & 348 & 312 & 235 & 102 & 348 & 312 & 235 & 102 \\
\hline DIFclan & 0.018 & 0.012 & 0.013 & 0.039 & -0.039 & -0.049 & -0.041 & 0.021 \\
\hline DIFadho & -0.039 & -0.053 & -0.101 & -0.045 & -0.026 & -0.028 & -0.093 & -0.112 \\
\hline DIFmark & 0.026 & 0.033 & 0.064 & 0.012 & 0.080 & 0.091 & $0.128^{* *}$ & 0.064 \\
\hline DIFhier & -0.015 & -0.007 & -0.007 & -0.009 & 0.015 & 0.023 & 0.005 & -0.060 \\
\hline ADIFclan & -0.034 & -0.051 & -0.086 & -0.077 & -0.072 & -0.087 & $-0.128^{* *}$ & -0.125 \\
\hline ADIFadho & -0.054 & -0.052 & -0.121 & $-0.209^{* *}$ & -0.032 & -0.023 & -0.091 & $-0.183^{*}$ \\
\hline ADIFmark & -0.025 & -0.036 & -0.105 & $-0.165^{*}$ & -0.020 & -0.040 & $-0.119^{*}$ & -0.146 \\
\hline ADIFhier & $-0.115^{* *}$ & $-0.132^{* *}$ & $-0.206^{* * *}$ & $-0.267^{* *}$ & $-0.104^{*}$ & $-0.1111^{* *}$ & $-0.185^{* * *}$ & $-0.195^{* *}$ \\
\hline minADIF & -0.051 & -0.059 & $-0.126^{*}$ & $-0.173^{*}$ & -0.074 & -0.071 & $-0.110^{*}$ & -0.133 \\
\hline aveADIF & -0.074 & -0.088 & $-0.177^{* *}$ & $-0.236^{* *}$ & -0.082 & $-0.098^{*}$ & $-0.186^{* * *}$ & $-0.245^{* *}$ \\
\hline maxADIF & -0.066 & -0.078 & $-0.156^{* *}$ & $-0.207^{* *}$ & -0.067 & -0.083 & $-0.177^{* * *}$ & $-0.224^{* *}$ \\
\hline
\end{tabular}

Note: ${ }^{*} p<0.10,{ }^{* *} p<0.05,{ }^{* * *} p<0.01$.

The results in Table 7 support the hypothesis that there is a positive connection between cultural fit and academic performance. In the table it is represented as the negative correlations and rank correlations between the absolute values of the differences between the preferred or perceived culture and the standardized self-reported average grade performance (aveADIF). However, the relationship is very weak (between -0.18 and -0.25 ), and the average and maximum absolute difference shows a significant connection with the performance only in the subsamples of those respondents who reported a minimum $61 \%$ and $81 \%$ attendance rate at the classes. The role of a relatively high attendance seems to be reasonable, since those who are not present at the majority of the lessons may not be able to estimate the culture appropriately and/or may not be motivated to get good grades; thus the measurement may be heavily biased in their case.

Nevertheless, mismatch in the hierarchy type presents a significant negative correlation in all samples, and a significant negative rank correlation for all but the sample of the minimum $21 \%$ attendance. Thus, its relationship with the performance is significant even when that of the average and maximum values are not. The fit of the other culture types shows no consistent statistically significant linear or rank correlation with the performance (ADIFadho and ADIFclan are significant in only one case each, and even in these cases the linear and rank correlations do not support each other). Still, it is supportive for our hypothesis that the coefficients - significant or not are negative in every case without exception.

The relationships between the signed variances of the preferred/perceived culture types and the performance did not produce any consistent pattern (the only significant connection is the rank correlation between the DIFmark and the performance in the case of the minimum $61 \%$ 
attendance).

In sum, our results support the assumption that if the preferred and perceived cultures are closer to each other, especially in the case of hierarchy, the average grades are expected to increase (the connection is weak). We have to note, however, that correlation analysis says nothing about causality; thus we cannot tell whether the cultural fit helps the students to get better grades, or students with better grades tend to feel the culture to be a better fit for them.

Next, we employ linear regression analysis to test the above findings in the presence of some demographic variables available from the survey (sex, age, habitation, secondary school type, self-reported class attendance rate, being employed or not). We will investigate only those variables of cultural fit that were found to be significant above, i.e. absolute differences of the four culture types (we expect that only hierarchy will be significant) and the average absolute difference (this showed a stronger relationship than the minimum or maximum absolute difference). In both cases only the constant and the independent variables with significant contributions are included in the models. We start with the average absolute difference as the main independent variable; see Table 8 for the results.

Table 8.

\section{Linear regression analysis with average absolute} cultural difference

\begin{tabular}{|c|c|c|c|c|}
\hline \multirow{3}{*}{$\begin{array}{l}\text { Dependent var- } \\
\text { iable }\end{array}$} & \multicolumn{4}{|c|}{ Subsample by minimum attendance rate } \\
\hline & $\min .21 \%$ & $\min .41 \%$ & \begin{tabular}{|l|}
$\min .61 \%$ \\
\end{tabular} & $\min .81 \%$ \\
\hline & ZPERF & ZPERF & ZPERF & ZPERF \\
\hline Constant & $\begin{array}{c}0.027 \\
(0.367) \\
\end{array}$ & $\begin{array}{c}0.054 \\
(0.703) \\
\end{array}$ & $\begin{array}{c}0.368 \\
\left(2.952^{* * *}\right) \\
\end{array}$ & $\begin{array}{c}0.703 \\
\left(4.202^{* * *}\right) \\
\end{array}$ \\
\hline SEX & - & - & $\begin{array}{c}0.253 \\
\left(2.097^{* *}\right)\end{array}$ & - \\
\hline AGE & - & - & - & - \\
\hline LOCAL & - & - & - & - \\
\hline VOCED & $\begin{array}{c}-0.343 \\
\left(-3.143^{* * *}\right)\end{array}$ & $\begin{array}{c}-0.339 \\
\left(-2.961^{* * *}\right)\end{array}$ & $\begin{array}{c}-0.470 \\
\left(-3.654^{* * *}\right)\end{array}$ & $\begin{array}{c}-0.520 \\
\left(-2.500^{* *}\right)\end{array}$ \\
\hline ATT41 & - & - & - & - \\
\hline ATT61 & - & - & - & - \\
\hline ATT81 & $\begin{array}{c}0.314 \\
\left(2.771^{* * *}\right)\end{array}$ & $\begin{array}{c}0.286 \\
\left(2.482^{* *}\right)\end{array}$ & - & - \\
\hline JOB & - & - & - & - \\
\hline aveADIF & - & - & $\begin{array}{c}-0.039 \\
\left(-2.774^{* * *}\right) \\
\end{array}$ & $\begin{array}{c}-0.058 \\
\left(-2.578^{* *}\right) \\
\end{array}$ \\
\hline $\mathrm{F}$ & $9.217^{* * * *}$ & $7.798^{* * * *}$ & $8.404^{* * *}$ & $6.217^{* * *}$ \\
\hline $\operatorname{adj} R^{2}$ & 0.045 & 0.042 & 0.087 & 0.094 \\
\hline $\mathrm{N}$ & 348 & 312 & 235 & 102 \\
\hline
\end{tabular}

Note: $F=$ ANOVA $F$ statistic, adj $R^{2}$ is the variance explained (unbiased), $t$-statistics are in parentheses, ${ }^{*} p<0.10,{ }^{* *} p<0.05,{ }^{* * *} p<0.01$.

The results presented in Table 8 support the inferences drawn from the linear and rank correlation analyses: among students who attend more than $60 \%$ of the classes there is a significant, negative relationship between cultural non-fit (aveADIF) and academic performance (ZPERF), even when sex, age, habitation, secondary school type, class attendance rate, and employment during university are taken into consideration. The explanatory power of the regression models are very weak (adjusted $R^{2}<0.1$ ), thus this is certainly not among the main factors affecting students' success at the university. However, the hypothesized connection is supported.

Lower levels of class attendance aveADIF did not contribute significantly to the models (instead, the dummy variable of attendance above $80 \%$ was significant). From these results we can assume that cultural fit becomes important only when an appropriate level of attendance is already given. Until then, the effect of attendance suppresses it.

Now, let us consider the test for the contribution of cultural fit in separate culture types (instead of the average cultural fit tested above) to the students' performance (see Table 9).

Table 9.

Linear regression analysis with absolute differences in the four culture types

\begin{tabular}{|c|c|c|c|c|}
\hline \multirow{3}{*}{$\begin{array}{l}\text { Dependent } \\
\text { variable }\end{array}$} & \multicolumn{4}{|c|}{ Subsample by minimum attendance rate } \\
\hline & $\min .21 \%$ & $\min .41 \%$ & $\min .61 \%$ & $\min .81 \%$ \\
\hline & ZPERF & ZPERF & ZPERF & ZPERF \\
\hline Constant & $\begin{array}{c}0.121 \\
(1.387)\end{array}$ & $\begin{array}{c}0.163 \\
\left(1.767^{*}\right)\end{array}$ & $\begin{array}{c}0.299 \\
\left(2.747^{* * *}\right)\end{array}$ & $\begin{array}{c}0.618 \\
\left(4.310^{* * *}\right)\end{array}$ \\
\hline SEX & - & - & $\begin{array}{c}0.238^{*} \\
(1.965)\end{array}$ & - \\
\hline AGE & - & - & - & - \\
\hline LOCAL & - & - & - & - \\
\hline VOCED & $\begin{array}{c}-0.332 \\
\left(-3.050^{* * *}\right) \\
\end{array}$ & $\begin{array}{c}-0.322 \\
\left(-2.815^{* * *}\right) \\
\end{array}$ & $\begin{array}{c}-0.431 \\
\left(-3.336^{* * *}\right) \\
\end{array}$ & $\begin{array}{c}-0.458 \\
\left(-2.203^{* *}\right) \\
\end{array}$ \\
\hline ATT41 & - & - & - & - \\
\hline ATT61 & - & - & - & - \\
\hline ATT81 & $\begin{array}{c}0.307 \\
\left(2.715^{* * *}\right)\end{array}$ & $\begin{array}{c}0.281 \\
\left(2.451^{* *}\right)\end{array}$ & - & - \\
\hline JOB & - & - & - & - \\
\hline ADIFclan & - & - & - & - \\
\hline ADIFadho & - & - & - & - \\
\hline ADIFmark & - & - & - & - \\
\hline ADIFhier & $\begin{array}{c}-0.018 \\
\left(-1.932^{*}\right)\end{array}$ & $\begin{array}{c}-0.021 \\
\left(-2.113^{* *}\right)\end{array}$ & $\begin{array}{c}-0.031 \\
\left(-2.796^{* * *}\right) \\
\end{array}$ & $\begin{array}{c}-0.047 \\
\left(-2.650^{* * *}\right) \\
\end{array}$ \\
\hline $\mathrm{F}$ & $7.438^{* * *}$ & $6.746^{* * *}$ & $8.448^{* * *}$ & $6.415^{* * *}$ \\
\hline $\operatorname{adj} R^{2}$ & 0.053 & 0.053 & 0.087 & 0.097 \\
\hline $\mathrm{N}$ & 348 & 312 & 235 & 102 \\
\hline
\end{tabular}

Note: $F=$ ANOVA F statistic, adj $R^{2}$ is the variance explained (unbiased), $t$-statistics are in parentheses, ${ }^{*} p<0.10,{ }^{* *} p<0.05,{ }^{* * *} p<0.01$.

The regression models of Table 9 generally support the previous findings. Among students with attendance rates above $40 \%, 60 \%$, and $80 \%$ the absolute difference between the preferred and perceived hierarchy culture contributes significantly to the explanation of the standardized grades. However, in the sample with $21 \%$ minimum attendance, it is significant only at the $10 \%$ level. In all these cases the coefficient on ADIFhier is negative, thus a greater difference leads to a weaker student performance in the regression models (deductively, a better cultural fit leads to a stronger performance). None of the other three culture types' mis- 
match showed a significant effect on the dependent variable.

\section{Conclusion and Discussion}

This paper has discussed the connection between cultural fit and the academic performance of higher education students. Cultural fit was estimated inversely as the absolute value of the difference between preferred and perceived culture measured by OCAI questionnaires filled in by students from the University of Debrecen, Hungary. The academic performance was estimated based on the surveyed students' self-reported average grade standardized by their major and semester of enrolment.

By using different statistical methods (linear correlation analysis, rank correlation analysis, linear regression analysis) the above connection was found to be significant in the case of hierarchy culture and the average of the cultural mismatches of the four culture types. In addition, the maximum mismatch was also supported to be linearly correlated, as well as rank correlated to the standardized grade performance; however, this was not tested with linear regression analysis.

The above mentioned statistical relationships were present only if the subsample of those students who visited the majority of the classes was analyzed (in the case of hierarchy culture to have visited at least $40 \%$ of the classes was sufficient).

Based on the results reported above we can conclude that the answer to the research question is: yes, higher education students' cultural fit tends to relate positively to their academic performance. In other words, the related hypothesis is supported, as well as the results of previous educational science research (e.g. Sommet et al., 2015; Bowman - Denson, 2014; Stephens et al., 2014). The main contribution of this paper is the introduction of a new methodology to this area: we have applied a culture diagnostic concept (CVF) and a tool (OCAI) that had been developed in the managerial sciences. Using OCAI for the measurement of cultural fit instead of simply the perceived and/or preferred culture and examining its relationship with student performance is also a novelty in the managerial OC literature about HEIs.

To suitably evaluate the findings, we should make some additional comments. First, the applied methods could not reveal causal directions. Thus, it is equally possible that the cultural fit contributes to academic success, that being more successful in one's studies makes the student like the given organizational culture more, or there can also be an unidentified common cause behind both stronger cultural fitness and better study grades. Any combination of these interpretations is also possible.

Second, and strongly connected to the first point, a clear advice on managerial responses cannot be given at this stage. In other words, the research conclusions are not normative. Even if we accept that a stronger culture-person fit could increase the organizational performance (in the actual study: grade averages) it is still only one component in a very complex system of variables. It should be taken into consideration, but other factors (the motivating effect of the culture type in itself, students' background, skills and abilities, etc.) could be at least as important. For example, based on the combined facts that the average student seems to prefer a weaker hierarchy culture (as we can see in Table 6) and that a better fit between the preferred and perceived levels of hierarchy culture is connected to a higher performance (Table 7) we should not automatically conclude that the institution should lower the level of its hierarchy culture. A stronger hierarchy culture could have benefits that were not tested in our paper. The management might find it more appropriate - mentioning only two examples - to help their students accept the given cultural features, or to involve information about its culture in its recruitment activities to attract those whose will find the existing culture acceptable.

Third, the connection between cultural fit and performance was present only for those students who were present at more than $40 \%$ of the classes. In other words, cultural fit could influence only those who have enough opportunity to perceive it. During online or correspondence education programs we can expect the relationship to be weaker or not to exist at all.

Naturally, some limitations must be mentioned along with the findings. First, the sample included students from only one university. Other institutions, preferably with different national and/or professional cultural backgrounds, might provide different results. Second, we collected the information about the culture through adapted OCAI questionnaires. Examinations with other cultural models and measurement methods (from Table 1 we can mention OCES, OCS, UES, and CCS) are needed to support our findings before we can conclude anything in general (the definition and diagnosis of organizational culture is still debated, see the literature review). Third, self-reported academic performance may be biased, thus more objective data would need to be analyzed to support or reject our conclusions.

In other words, the most trivial possible future research directions involve testing the findings of this paper through concentrating on its limitations using different samples, culture models and measurement methods, and more objective data about performance. Another interesting field for examinations could be to test the connections between individual cultural fitness and some additional performance measures. Important performance indicators of higher education institutions - among others - could be: graduation rate, graduate employability, retention (or dropout) rate, students' competition and research success.

Even with the limitations and considerations mentioned above, the results of this paper contribute to the literature in at least one important sense: they support the idea that cultural fit - as the students perceive it - can play a significant role in academic performance at higher education institutions, and managerial OC diagnosing tools could be an efficient help in managing this fit. Cultural management should be considered to be a part of the efforts made by higher education institutions to improve not only student satisfaction but also the output of their core operations. 


\section{REFERENCES}

Adkins, B. - Caldwell, D. (2004): Firm or subgroup culture: where does fitting in matter most? Journal of Organizational Behavior, 25(8), p. 969-978.

Alfes, K.-Shantz, A.-Alahakone, R. (2016): Testing additive versus interactive effects of person-organization fit and organizational trust on engagement and performance. Personnel Review, 45(6), p. 1323-1339.

Alvesson, M. (2013): Understanding Organizational Culture London: Sage

Balogh, A. - Gaál, Z. - Szabó, L. (2011): Relationship between organizational culture and cultural intelligence. Management \& Marketing: Challenges for the Knowledge Society, 6(1), p. 95-110.

Basir, S. A. - Davies, J. - Douglas, J. - Douglas, A. (2017): The influence of academic culture on quality management system ISO 9001 maintenance within Malaysian universities. Journal of Higher Education Policy \& Management, 39(3), p. 320-340.

Bencsik, A. - Marosi, I. - Döry T. (2012): Vágyott kultúra és reális értékítélet - Tudásmenedzsmentrendszer kiépítésének előfeltétele egy felsőoktatási intézményben. Vezetéstudomány, 43(5), p. 25-40.

Bowman, N. A. - Denson, N. (2014): A missing piece of the departure puzzle: student-institution fit and intent to persist. Research in Higher Education, 55(2), p. 123-142.

Burchell, N. - Kolb, D. (2003): Pattern Matching Organisational Cultures. Journal of Management \& Organization, 9(3), p. 50-61.

Burnes, B. (2009): Managing change. Fifth edition. Essex: Pearson Education

Caldwell, D. F. - O'Reilly III, C. A. (1990): Measuring person-job fit with a profile comparison process. Journal of Applied Psychology, 75(6), p. 648-657.

Cameron, K. S. - Ettington, D. R. (1988): The conceptual foundations of organizational culture. In: Smart, J.C. (ed.): Higher education: handbook of theory and research. (2) Norwell, MA: Kluwer, p. 356-396.

Cameron, K. S. - Quinn, R. E. (2006): Diagnosing and changing organizational culture. San Francisco, CA: Jossey-Bass

Carroll, D. T. (1983): A disappointing search for excellence. Harvard Business Review, 68(6), p. 78-88.

Castellanos, J. - Gloria, A. M. - Besson, D. - Harvey, L. $O$. C. (2016): Mentoring matters: racial ethnic minority undergraduates' cultural fit, mentorship, and college and life satisfaction. Journal of College Reading and Learning, 46(2), p. 81-98.

Chandler, N. - Heidrich B. (2014): Hajsza közben - egy magyar felsőoktatási intézmény piacorientációjának kultúraalapú elemzési kísérlete. Vezetéstudomány, 45(6), p. 27-36.

Chatman, J. A. (1989): Improving interactional organizational research: a model of personorganizational fit. Academy of Management Review, 14(3), p. 333-349.

Chidambaranathan, K. - Regha, V. S. (2016): Diagnosing the organizational culture of higher education libraries in the United Arab Emirates using the competing values framework. Libres, 26(2), p. 99-112.

Cooke, R. A. - Rousseau, D. M. (1988): Behavioral norms and expectations: a quantitative approach to the assessment of organizational culture. Group and Organizational Studies, 13(3), p. 245-273.

Fekete, H. - Dimény, E. (2012): Megfelelő kultúra = kiváló teljesítmény? Vezetéstudomány, 43 (4): p. 36-47.

Ferreira, A. I. - Hill, M. M. (2008): Organisational cultures in public and private. Portuguese universities: a case study. Higher Education, 55(6), p. 637-650.

Fralinger, B. - Olson, V. (2007): Organizational culture at the university level: a study using the OCAI instrument. Journal of College Teaching and Learning, 4(11), p. 85-98.

Glaser, S. R. - Zamanou, S. (1987): Measuring and interpreting organizational culture. Management Communication Quarterly, 1(2), p. 173-198.

Gordon, G. G. -DiTomaso, N. (1992): Predicting corporate performance from organizational culture. Journal of Management Studies, 29(6), p. 783-798.

Hajnal, Gy. (2006): Kultúra és teljesítmény a közigazgatásban. Vezetéstudomány, 37(4), p. 2-9.

Heidrich, B. - Chandler, N. (2015): Four seasons in one day: the different shades of organizational culture in higher education. Management Dynamics in the Knowledge Economy, 3(4), p. 559-588.

Hofstede, G. - Neuijen, B. - Ohayv, D. D. - Sanders, $G$. (1990): Measuring organizational cultures: a qualitative and quantitative study across twenty cases. Administrative Science Quarterly, 35(2), p. 286-316.

Iriana, R. - F. Buttle-Ang, L. (2013): Does organisational culture influence CRM's financial outcomes? Journal of Marketing Management, 29(3-4), p. 467-493.

Kleijnen, J. - Dolmans, D. - Muijtjens, A. - Willems, J. Van Hout, H. (2009): Organizational values in higher education: perceptions and preferences of staff. Quality in Higher Education, 15(3), p. 233-249.

Kleijnen, J. - Dolmans, D. - Willems, J. - Van Hout, H. (2011): Teachers' conceptions of quality and organisational values in higher education: compliance or enhancement? Assessment \& Evaluation in Higher Education, 38(2), p. 152-166.

Klein, A. - Wallis, J. - Cooke, R. (2013): The impact of leadership styles on organizational culture and firm effectiveness: An empirical study. Journal of Management \& Organization, 19(3), p. 241-254.

Kotter, J. P. - Heskett, J. L. (1992): Corporate culture and performance. New York, NY: The Free Press.

Kristof-Brown, A. L. - Zimmerman, R. D. - Johnson, E. $C$. (2005): Consequences of individuals' fit at work: a meta-analysis of person-job, person-organization, person-group and person-supervisor fit. Personnel Psychology, 58(2), p. 281-342.

Kuh, G. D. - Whitt, E. J. (1988): The invisible tapestry. Culture in American colleges and universities. ASHE-ERIC Higher Education, Report 1. Ottawa, ON: Association for the Study of Higher Education, 
Canadian Association of University Teachers

Lauver, K. J. - Kristof-Brown, A. L. (2001): Distinguishing between employees' perceptions of person-job and person-organization fit. Journal of Vocational Behavior, 59(3), p. 454-470.

Lawler III, E. E. (1985): Challenging traditional research assumptions. In: Lawler, III, E. E. - Mohrman, Jr., A. M. - Mohrman, S. A. - Ledford, Jr., G. E. - Cummings, T. G. and associates (eds.): Doing Research That Is Useful for Theory and Practice. San Francisco, CA: Jossey-Bass, p. 1-17.

Lee S. K. J. - Yu, K. (2004): Corporate culture and organizational performance. Journal of Managerial Psychology, 19(4), p. 340-359.

Lim, B. (1995): Examining the organizational culture and organizational performance link. Leadership \& Organization Development Journal, 16(5), p. 16-21.

Marcoulides, G. A. - Heck, R. H. (1993): Organizational culture and performance: proposing and testing a model. Organization Science, 4(2), p. 209-225.

Meyer, J. P. - Hecht, T. D. - Gill, H., - Toplonytsky, L. (2010): Person-organization (culture) fit and employee commitment under conditions of organizational change: A longitudinal study. Journal of Vocational Behavior, 76(3), p. 458-473.

Ogbonna, E. - Harris, L. C. (2000): Leadership style, organizational culture and performance: empirical evidence from UK companies. International Journal of Human Resource Management, 11(4), p. 766-788.

O'Reilly III, C. A. - Chatman, J. - Caldwell, D. F. (1991): People and organizational culture: a profile comparison approach to assessing person-organizational fit. Academy of Management Journal, 34(3), p. 487-516.

Pinho, J. C. - Rodrigues, A. P. - Dibb, S. (2014): The role of corporate culture, market orientation and organizational commitment in organizational performance: the case of non-profit organizations. Journal of Management Development, 33(4), p. 374-398.

Pushnykh, V. - Chemeris, V. (2006): Study of a Russian university's organisational culture in transition from planned to market economy. Tertiary Education and Management, 12(2), p. 161-182.

Schein, E. H. (1990): Organizational culture. American Psychologist, 45(2), p. 109-119.

Schein, E. H. (2010): Organizational culture and leadership. 4th edition. San Francisco, CA: Jossey-Bass.

Schneider, B. - Ehrhart, M. G. - Macey, W. H. (2013): Organizational climate and culture. Annual Review of Psychology, 64(1), p. 361-388.

Shirbagi, N. (2007): Egyetemi oktatók szervezeti elkötelezettsége, és annak kapcsolata a szervezeti kultúrával. Magyar Pedagógia, 107(3), p. 185-203.

Sommet, N. - Quiamzade, A. - Jury, M. - Mugny, G. (2015): The student-institution fit at university: interactive effects of academic competition and social class on achievement goals. Frontiers in Psychology, 6. Stephens, N. M. - Fryberg, S. A. - Markus, H. R. -Johnson, C. S. - Covarrubias, R. (2012): Unseen disadvantage: how American universities' focus on independence undermines the academic performance of firstgeneration college students. Journal of Personality and Social Psychology, 102(6), p. 1178-1197.

Stephens, N.M.-Townsend, S. S.-Markus, H. R.-Phillips, L. T. (2012): A cultural mismatch: independent cultural norms produce greater increases in cortisol and more negative emotions among first-generation college students. Journal of Experimental Social Psychology, 48(6), p. 1389-1393.

Stephens, N. M. - Hamedani, M. G. - Destin, M. (2014): Closing the social-class achievement gap: a difference-education intervention improves firstgeneration student' academic performance and all student' college transition. Psychological Science, 25(4), p. 943-953.

Suderman, J. (2012): Using the Organizational Cultural Assessment (OCAI) as a tool for new team development. Journal of Practical Consulting, 4(1), p. 52-58.

Tierney, W. G. (1988): Organizational culture in higher education: defining the essentials. The Journal of Higher Education, 59(1), p. 2-21.

Trice, H. M. - Beyer, J. M. (1993): The cultures of work organizations. Englewood Cliffs, NJ: Prentice-Hall

UD (2018): University of Debrecen: Some Facts and Figures. University of Debrecen. https://unideb.hu/en/ university-debrecen-some-facts-and-figures

Van den Berg, P. T. - Wilderom, C. P. M. (2004): Defining, measuring, and comparing organisational cultures. Applied Psychology: An International Review, 53(4), p. 570-582.

Van der Velden, G. (2012): Institutional level student engagement and organizational cultures. Higher Education Quarterly, 66(3), p. 227-247.

Wei, Y. (2013): Person-organization fit and organizational citizenship behavior: Time perspective. Journal of Management \& Organization, 19(1), p. 101-114.

West-Moynes, M. H. (2012): A study of organizational culture in Ontario colleges with high student satisfaction. $\mathrm{PhD}$ diss., https://tspace.library. utoronto.ca/bitstream/1807/32848/3/West-Moynes MaryLynn_H_201206_PhD_thesis.pdf

Zhu, C. (2015): Organisation and technology-enhanced innovation in higher education. Technology, Pedagogy \& Education, 24(1), p. 65-79.

Zhu, C. - Engels, N. (2014): Organizational culture and instructional innovations in higher education: Perceptions and reactions of teachers and students. Educational Management Administration \& Leadership, 42(1), p. 136-158. 